\section{Horticultural Crop Production in High Tunnels in the United States: A Snapshot}

\author{
Edward E. Carey ${ }^{1,5}$, Lewis Jett ${ }^{2}$, William J. Lamont Jr. ${ }^{3}$, \\ Terrance T. Nennich ${ }^{4}$, Michael D. Orzolek ${ }^{3}$, \\ and Kimberly A. Williams ${ }^{1}$
}

ADDITIONAL INDEX wORDs. hoop house, protected agriculture, controlled environment agriculture, vegetable, fruit, flower

SuMMARY. High tunnels are becoming an increasingly important production tool for vegetable, small fruit, and cut flower growers in many parts of the United States. They provide a protected environment relative to the open field, allowing for earlier or later production of many crops, and they typically improve yield and quality as well as disease and pest management. Producers, ranging from small-scale market gardens to larger scale farms, are using high tunnels of various forms to produce for early markets, schedule production through extended seasons, grow specialty crops that require some environmental modification, and capture premium prices. The rapid ongoing adoption of high tunnels has resulted in numerous grower innovations and increased university research and extension programming to serve grower needs. An informal survey of extension specialists was conducted in 2007 to estimate numbers (area) of high tunnels and crops being grown in them by state, and to identify current research and extension efforts. Results of this survey provide an indication of the increasing importance of these structures for horticultural crop production across the country.

$\mathrm{P}$ roducers of horticultural crops in the United States, and the research and extension specialists who assist them, are increasingly recognizing high tunnels as valuable tools to assist with season extension and crop protection. High tunnels are also sometimes called hoop houses or unheated greenhouses and they include a range of designs from single-span to multi-span structures that are usually covered with a single layer of 6-mil polyethylene greenhouse film. High tunnels may be constructed to be semipermanent, movable, or temporary, although they are usually considered temporary structures for purposes of property assessment and taxation (Blomgren and Frisch, 2007). Typically, high tunnels are unheated and are passively ventilated, but they must have water for

We gratefully acknowledge the generous responses of all the survey respondents. Contribution no. 09-146-J of the Kansas Agricultural Experiment Station.

${ }^{1}$ Department of Horticulture, Forestry, and Recreation Resources, Kansas State University, 35230 W 135th Street Manhattan, KS 66506

${ }^{2}$ Agriculture and Natural Resources Unit, West Virginia University, Morgantown, WV 26506

${ }^{3}$ Department of Horticulture, Pennsylvania State University, University Park, PA 16802

${ }^{4}$ North Central Research and Outreach Center, University of Minnesota, Crookston, MN 56716

${ }^{5}$ Corresponding author. E-mail: tcarey@ksu.edu. irrigation, and are used to produce a wide variety of crops directly in the soil, or less frequently, in artificial media (Lamont et al., 2003; Heidenreich et al., 2008). In regions with winter snow and ice, the polyethylene film is generally removed from multi-span high tunnels during the winter months, while it is usually left on single-span tunnels, which are often used for the production of winter crops (Blomgren and Frisch, 2007).

Despite having been invented in the United States (Emmert, 1955), high tunnels have not been adopted as quickly by fruit, vegetable, and flower growers here as in many other countries (Wittwer, 1993). While high tunnels or overwintering structures have been widely used in the nursery industry, it was not until the early 1990s that research and extension professionals in the Northeast began to report the high potential of these structures for vegetable production (Wells and Loy, 1993), initially reporting their great advantage for early production of warm season crops such as tomato (Solanum lycopersicum). Multiple efforts, many by innovative growers (Blomgren and Frisch, 2007; Byczynski, 2003; Coleman, 1998, 1999; Wiediger and Wiediger, 2003), have contributed to today's increasing awareness of the potential value of high tunnels for early or extended season production of fruit, vegetable, and flowers of outstanding quality. Because of their low construction and operating costs, it is common for producers to recover their investment within 1 or 2 years (Blomgren and Frisch, 2007).

Today, the use of high tunnels is increasing rapidly in many places in the United States. There are many examples of research and extension programming and education resources being developed around the United States. (Jett, 2004; Jimenez et al., 2005; Lamont et al., 2002, 2005; Nennich et al., 2004). Information on the Internet about high tunnels and their uses has burgeoned over the past decade. Several universities, agencies, and businesses have published digital information about high tunnel construction and use. One university-sponsored website (Kansas State University, 2003) contains original content geared for grower and educator audiences, as well as links to other websites of interest. This website also provides access to an e-mail listserv that is widely used by growers, allied industry, and academics to ask questions and exchange information related to high tunnel use (Kansas State University, 2004).

To attempt to capture a snapshot of current high tunnel use nationwide, we conducted an informal survey of state extension specialists at land grant universities. We present the results of the survey in this article to highlight the growing body of high tunnel research, extension education, and usage by growers in the United States.

\section{Materials and methods}

From a list of horticulture extension educators at land grant universities

\begin{tabular}{lllc}
\hline $\begin{array}{l}\text { Units } \\
\begin{array}{l}\text { To convert U.S. to SI, } \\
\text { multiply by }\end{array}\end{array}$ & U.S. unit & SI unit & $\begin{array}{l}\text { To convert SI to U.S., } \\
\text { multiply by }\end{array}$ \\
\hline 0.4047 & acre(s) & $\mathrm{Ha}$ & 2.4711 \\
0.0929 & $\mathrm{ft}^{2}$ & $\mathrm{~m}^{2}$ & 10.7639 \\
0.0254 & $\mathrm{mil}$ & $\mathrm{Mm}$ & 39.3701
\end{tabular}


$\underset{\infty}{\infty}$ Table 1. Estimated area, number and types of high tunnels, and predominant crops cultivated in them, as reported by state in the United States in 2007. Information was obtained through an informal survey of state extension vegetable specialists and other experts in each state.

\begin{tabular}{|c|c|c|}
\hline State $^{\mathrm{z}}$ & $\begin{array}{l}\text { Estimated area } \\
(\text { (acres })^{\mathrm{y}}\end{array}$ & $\begin{array}{l}\text { Estimated high } \\
\text { tunnels (no.) }\end{array}$ \\
\hline
\end{tabular}

Alaska

Alabama

Arizona

California

Colorado

Connecticut

Delaware

Florida

Georgia

Hawaii

Illinois

Indiana

Iowa

Kansas

Kentucky

Maine

Maryland

Michigan

Minnesota

Mississippi

Missouri

Nebraska

New Hampshire

New Jersey

New Mexico

New York

North Carolina

North Dakota

Ohio

Oklahoma

Oregon

Pennsylvania acres

Many small

500-1000

$>4000$

1.1

50-100

10

Mainly multispan

24

Hundreds

5-10

About 1

100

Multispan

100

50

40

About 3

About 1

About 34

About 20

About 9

$<1$

About 7.5

About 5

About 8

60

About 17

Uncertain

$<1$

5-8

1-2

About 100

34
50

700-1000

40

$>5$ acres (single span), 20 acres (multispan) 200

Many small

100

100

Many single span, a few multispan

$>320$ units on

small farms

240

About 6

14 acres (single span), 20 acres (multispan)
Green bean (Phaseolus pulgaris), tomato (Solanum lycopersicum), cucumber (Cucumis sativus), greens, herbs

Tomato, okra (Abelmoschus esculentum), pepper (Capsicum annuum), cut flowers

Ornamentals

Raspberry (Rubus spp.), flowers, some vegetables

Salad greens, tomato, flowers, herbs

Primarily nursery crops, limited vegetables

Tomato, squash (Cucurbita pepo)

Oriental and leafy vegetables, strawberry (Fragaria $\times$ ananassa), raspberry

Transplant production of leafy vegetable crops such as lettuce (Lactuca sativa) and crucifers (Brassica spp.), various organic crops

Tomato and pepper (50 acres), flowers (50 acres)

Tomato, many other crops

Tomato, salad greens, strawberry, pepper

Tomato, greens, cole crops, cut flowers, some herbs

Tomato, pepper, lettuce, greens, cut flowers

Tomato, pepper, lettuce

Tomato, greens, flowers, cucumber, pepper, zucchini (Cucurbita pepo), raspberry

Tomato, leafy greens, brambles (Rubus spp.)

Tomato, pepper, cucumber, fall/winter salad, mixed vegetables, raspberry, strawberry, sweet cherry (Prunus avium), grape (Vitis spp.)

Tomato, cucumber, pepper, eggplant (Solanum melongena), onion (Allium cepa), garlic (Allium sativum), lettuce, herbs

Pepper, tomato, squash, cut flowers, strawberry

Tomato, cucumber, onion, potato (Solanum tuberosum), strawberry, cut flowers, fig (Ficus carica)

Tomato, lettuce, salad mix, cucumber, vegetable transplants, cut flowers

Primarily tomato, numerous other vegetables, small fruit, cut flowers

Tomato, pepper, lettuce, raspberry, cut flowers and herbs

Tomato, lettuce, spinach, other vegetables (40 acres), flowers (20 acres),

Tomato, greens, pepper, cucumber

Tomato, mixed winter vegetables, early and late summer vegetables, flowers

Tomato, pepper, leafy vegetable transplants, small fruit (e.g., strawberry), flowers

Tomato, summer squash, cucumber, winter greens

Blackberry (Rubus spp.), blueberry (Vaccinium corymbosum)

Tomato, raspberry, lettuce, mixed greens, strawberry, cut flowers, herbs, organic production 


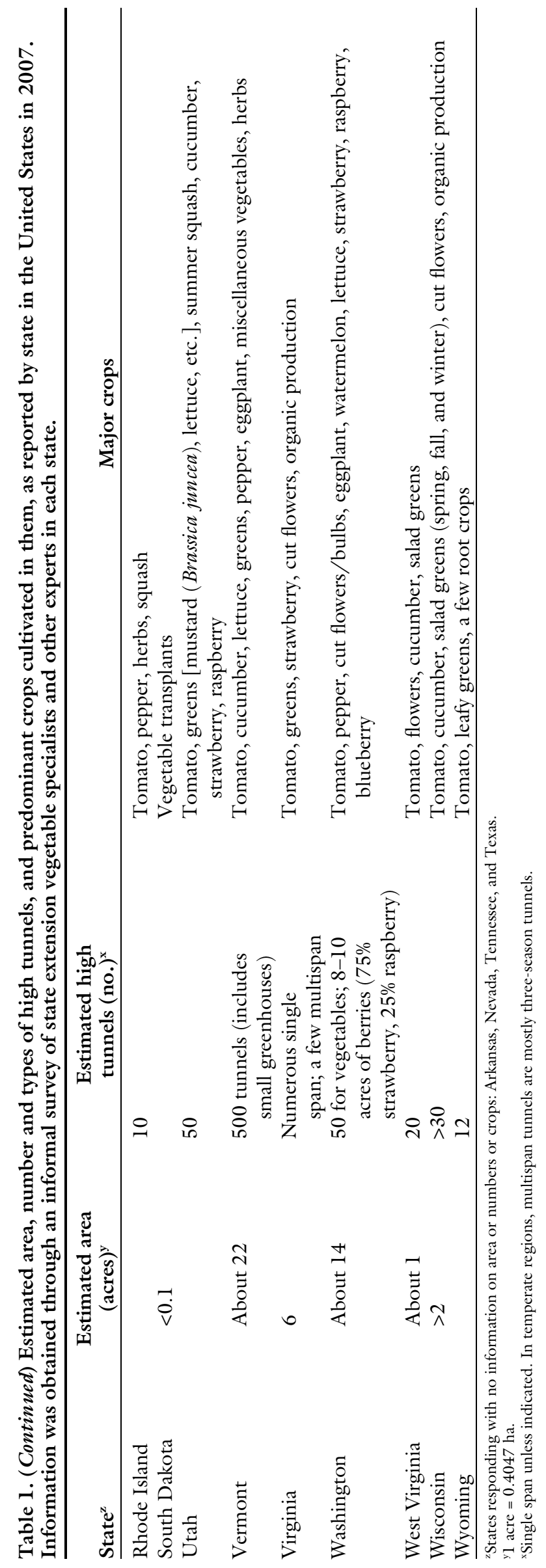

compiled by W.J. Lamont, Jr., when he served as ASHS Extension Division vice-president, we selected the names of vegetable or food crops specialists to be contacted in the $\mathbf{5 0}$ states. In many instances, the initial contacts consulted others to gather the information requested in the survey. The questions asked were: 1) What is the estimated number or area equivalent of high tunnels in your state?; 2) What are the principal crops being grown in high tunnels in your state?; 3) What is the focus of research or demonstration work in your state that you are aware of? Responses were received from 46 states and are presented in Tables 1 and 2.

\section{Results and discussion}

Table 1 lists estimates of high tunnel areas, numbers, and principal crops grown in them for states from which responses were received. Respondents were not consistent in their definition of high tunnels. Hence, some respondents included commercial flower production, nursery overwintering structures, or small heated greenhouses (e.g., Arizona, Rhode Island, and Vermont), while many reported tunnels used only for vegetable, fruit, and cut flower production by small acreage farmers. We included all responses received in the survey, but it should be understood that rather than presenting results that are strictly comparable from state to state, the responses are reflective of the high degree of variation in the number and use of high tunnels from state to state and of concomitant variation among states in awareness by extension workers of the current status of high tunnel use by growers in their state.

Most respondents reported that the numbers they provided were just their best guesses because there is currently no mechanism to accurately track high tunnel area, numbers, and crops in most states. The U.S. Department of Agriculture (USDA) census of agriculture does not distinguish between high tunnels and heated greenhouse structures (USDA, 2007). In our survey, some estimates of high tunnel area (e.g., Florida) seem high, but most estimates provided are probably conservative. We did not ask about the average size of operation, but the respondent from Illinois estimated this to be between one and 
t Table 2. High tunnel fruit, vegetable, and flower research, and demonstration activities reported by extension specialists and others by state in the United States in 2007. Selected references to previously published work are included by state.

\begin{tabular}{llrl}
\hline State & $\begin{array}{c}\text { Principal research/ } \\
\text { demo locations }\end{array}$ & Current research and demonstration topics, and reported results (selected references) ${ }^{\mathrm{z}}$
\end{tabular}

Alaska

Alabama

Auburn

Arkansas

Colorado

Fayetteville

Fort Collins, elsewhere

Delaware

Florida

Georgia

Hawaii

Illinois

Indiana

Iowa

Kansas

Kentucky

Maine

Maryland

Michigan

Athens

Manoa

St. Charles, Urbana

Ames, Harlan

Olathe, Wichita

Lexington

Orono

Eastern Shore

Lansing, Benton Harbor, Clarksville

Minnesota

Grand Rapids, Staples,

Crookston (organic), Waseca
Initial stages of research; will crops even survive the winter (Karlsson et al., 2007; Rader and Karlsson, 2006)?

Fall and spring tomato (Solanum lycopersicum), colored bell pepper (Capsicum annuum), strawberry

(Fragaria $\times a n a n a s s a)$, and cut snapdragon (Antirrbinum majus) evaluated with excellent results.

Organic bramble (Rubus spp.) production research with USDA Integrated Organic Program support.

$6000 \mathrm{ft}^{2}$ in tunnels dedicated to research of diverse vegetable and flower crops under different covering materials

focusing on insect-vectored disease mitigation (Organic Farming Research Foundation grant). Planning

blueberry (Vaccinium corymbosum) and strawberry work. Many growers are recipients of Colorado State

University Specialty Crops Program grower and education grants; their work included feasibility studies,

marketing studies, and climate studies. A new project supported by Sustainable Agriculture Research and

Education (SARE) program is integrating hog housing and vegetable production.

Raspberry (Rubus spp.) demonstration.

Weather protection, and improved fruit quality, especially with strawberry.

Testing the use of "quasi" tunnels as shelters to produce tomato and pepper during the summer/fall.

Research on simple, low-tech hydroponic systems for vegetable production with particular emphasis on tomato, watercress (Nasturtium officinale), ginger (Zingiber officinale), and potato (Solanum tuberosum); trying to find an inexpensive tank system and use a minimum of growing medium.

Studies of local acclimation, crop suitability, market opportunities, and sustainable optimization. We see high tunnels as a key tool for developing more sustainable production of fruit and vegetables and are looking to expand our work in that area.

Proposing larger-scale high tunnels in conjunction with biofuel production.

Cropping sequence for tomatoes, tracking production costs, and demonstration of high tunnel technology.

Research and demonstration in half-acre Haygrove ${ }^{y}$ three-season tunnel and in four-season single-span tunnels. Inside/outside comparisons, organic/conventional fertility management, and small fruit and vegetable research and demonstration (Kadir et al., 2006; Knewtson and Carey, 2007; Spaw and Williams, 2004; Zhao et al., 2007).

Demonstration in half-acre multibay and smaller single-span high tunnels (Bomford et al., 2007).

Variety evaluations, passive solar heating systems, soil health, cover cropping, and demonstrations.

Organic salad green production and pest [aphid (Aphididae), mite (Acari), and thrips (Thysanoptera)] control

Research on strawberry, raspberry, blueberry, sweet cherry (Prunus avium), pepper, and tomato

in multibay tunnels. For three-season and four-season tunnels, focus is on season extension, quality improvement, variety screening, enterprise budgeting, market research, farmer interviews to measure the viability of high tunnel technology, year-round production, training future farmers, organic production, direct marketing, risk management, training the trainer model for construction and usage, modeling crop production and timing schedules, economic analysis, benefits of season extension to farmer's markets and onfarm stores, online course development, agritourism, energy studies in comparison with imported produce (from outside Michigan), community development, effects of season extension on human health and wellbeing especially in terms of the elderly and rural communities, and the creation of model business plans for high tunnel users based on various marketing decisions (Lang, 2009; Montri and Biernbaum, 2009).

Variety trials, tomato pruning, spacing, fertility, slow-release fertilizer, intercropping, and irrigation. Numerous SARE producer grants are funded in the state (Nennich et al., 2004). 


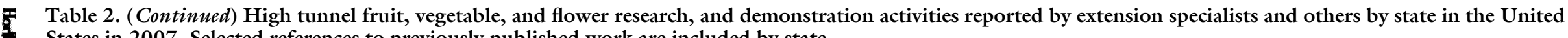
States in 2007 . Selected references to previously published work are included by state.

\section{State}

Mississippi

\section{Missouri}

Nebraska

New Hampshire

New Jersey

New Mexico

New York

North Carolina

Ohio

Oklahoma

Pennsylvania

Tennessee

Utah

Knoxville

Provo

\section{Principal research/ \\ demo locations}

Beaumont, Mississippi State

Columbia

Lincoln

Durham

Centerton, Brunswick

Northern New Mexico

Ithaca

Greensboro

Wooster

Lane, Ardmore (Noble

Foundation)

Rock Springs, elsewhere

Vermont

Virginia

Petersburg, Blackstone

Washington

Mount Vernon

West Virginia

Morgantown

Wisconsin

Green Bay

Laramie, Sheridan

\section{Current research and demonstration topics, and reported results (selected references) ${ }^{\mathrm{z}}$}

Vegetable and cut flower research.

No current activity. Previous vegetable and small fruit research in single-bay high tunnels (Jett, 2004, 2006).

Cut flowers, economics, microclimate modification, and biological control of insects and diseases.

Cut flower (Eustoma) production, early colored bell pepper variety trials, overwintering crucifers (Brassica spp.) for spring harvest, and tomato disease [leaf mold (Fulvia fulvum)] biocontrol (Wells, 1996; Wells and Loy, 1993).

Research on engineering aspects of high tunnels and tomato production (Both et al., 2007; Reiss et al., 2004).

Workshops on tunnel construction and use for smaller scale vegetable and ornamental production (Jimenez et al., 2005).

Biological pest management, crop rotation, impacts of different plastics on microclimate, cut flower and small fruit research, and on-farm applied research on cultural practices, varieties, and pest management (Blomgren and Frisch, 2007; Heidenreich et al., 2008; Wien, 2009).

Grafting tomato, small fruit (strawberry), and winter production of greens.

Season extension and testing soil fertility, organic transition, polyculture, and disease and insect management strategies or tools in conventional, sustainable, and organic systems and grafting.

Early carrot (Daucus carota) and onion (Allium cepa) transplant production, cherry/grape tomato variety trials and economics of high tunnel crop rotations: spinach (Spinacea oleracea)-tomato-squash (Cucurbita pepo) and annual strawberry-squash.

Specialty crops [ginger, watercress, and taro (Colocasia esculenta)], all vegetables (conventional and organic), strawberry, raspberry, blackberry, herbs, cut flowers, and hydroponic lettuce (Lactuca sativa). Applied research/demonstrations at 14 cooperative (growers or teachers/extension) high tunnels located throughout the state (Lamont, 1996; Lamont et al., 2002, 2003, 2005; Orzolek et al., 2004).

Plans for high tunnel research at new university organic farm.

Production information (organic and conventional) for winter (greens for late fall-early spring) and summer (tomato, squash, and pepper) crops, including production budgets. Raspberry in soil (permanent plantings) as well as in pots (pot-in-pot and aboveground pots) for season extension (early and late). Strawberry for spring annual production (in-ground and in-gutters). Growers cooperating around Utah as part of SARE grant for 2007 to 2010

Grafting greenhouse tomato, renewable energy (heating) systems, and organic production methods.

Season extension for small farmers who are direct marketing. Demonstration and research on crops include cut flowers, organic vegetables, raspberry, strawberry, tomato, various others. Work is conducted in $6000 \mathrm{ft}^{2} \mathrm{of}$ quonset tunnels and 21,000 $\mathrm{ft}^{2}$ Haygrove $^{\mathrm{y}}$. On-farm demonstrations on construction, season extension, and specialty crops. Virginia Tech Southern Piedmont Agricultural Research and Extension Center has a Haygrove $^{\mathrm{y}}$ around $21,000 \mathrm{ft}^{2}$, mainly for strawberry research.

Lettuce and Asian greens for winter production, watermelon (Citrullus lanatus)/tomato rain shelter effects, and strawberry, raspberry, and blueberry research (Miles and Labine, 1997).

Plan to build four high tunnels in 2007 for vegetable and strawberry research.

High tunnel microclimate and crop response, berry production that focuses on labor issues, and extension demonstration (Wright, 2005).

Strawberry, green pepper, cool season vegetables, tomato. 
four $2000-\mathrm{ft}^{2}$, single-bay tunnels. The average size of operation for multi-bay operations would be larger (several states reported these) because these typically have a minimum size of 0.5 acre. Mechanisms for more accurately tracking high tunnel acreage, crops, and grower needs would be desirable.

While many crops were reported to be grown in high tunnels (Table 1), the widespread importance of some crops was noteworthy. For most states, tomato was among the first crops reported. High-tunnel tomato crops are typically ready to market earlier than the field-grown crop, and they typically produce a higher quality crop with fewer requirements for inputs (Blomgren and Frisch, 2007; Jett, 2004; Nennich et al., 2004). The extent to which high tunnels are used for fall and winter production of cool season leafy green vegetables is not entirely clear from Table 1, but this is likely an important component of production in many states of the continental United States, ranging from Michigan to New Mexico. The widespread reporting of cut flowers is noteworthy, as are reports of small fruit production from many states, affirming that these crops can be profitable in high tunnels (Heidenreich et al., 2008; Wien, 2009). High tunnels are amenable to large-scale production, with raspberry (Rubus spp.) production in California being the most striking example, but in most states, high tunnels are being used by relatively small-scale producers to serve local markets (Table 1).

Table 2 summarizes high tunnel vegetable, fruit, and flower research and extension activities reported by state. Again, the list is certainly not complete, but it indicates that horticultural researchers and extension personnel in many states reported conducting activities aimed at assessing the potential of high tunnels, of researching particular production systems or problems, or demonstrating the benefits of high tunnels. The large number of states with active or incipient programs, and the large number of crops and management topics being addressed are indicative of significant needs and opportunities for high tunnel research and extension around the country, and of funding opportunities to help support these efforts. Because high tunnels are unheated and passively cooled, crop selection and management will be determined by local environmental conditions. This, and the previous lack of research on high-tunnel production systems in the United States, provide a strong justification for broadly decentralized research and extension efforts.

\section{Conclusions}

From the results of the survey and literature cited, it is evident that producer interest in and adoption of high tunnels is high, and there is a wide variety of research and extension activities ongoing around the country. In most places, high tunnel fruit, vegetable, and flower production, and research and extension efforts are primarily geared toward responding to growing demand for fresh, locally grown produce. With the considerable environmental protection that high tunnels provide to crops, and with growing producer awareness of the advantages these structures provide, continued expansion of acreage and diversification of crops grown in high tunnels is likely in the United States. We can look forward to an expanding body of research and practical knowledge to meet the needs of producers.

\section{Literature cited}

Blomgren, T. and T. Frisch. 2007. High tunnels: Using low-cost technology to increase yields, improve quality and extend the season. 27 Jan. 2008. <http:// www.uvm.edu/sustainableagriculture/ hightunnels.html>.

Bomford, M., A. Silvernail, and B. Geier. 2007. Season extension with high tunnels in Kentucky. HortScience 42:988 (Abstr.).

Both, A.J., E. Reiss, J.F. Sudal, K.E. Holmstrom, C.A. Wyenandt, W.L. Kline, and S.A. Garrison. 2007. Evaluation of a manual energy curtain for tomato production in high tunnels. Hort Technology 17:467-472.

Byczynski, L. (ed.). 2003. The hoophouse handbook. Growing For Market, Lawrence, KS.

Coleman, E. 1998. The winter harvest manual. Four Season Farm, Harborside, ME.

Coleman, E. 1999. Four-season harvest. Chelsea Green Publishing, White River Junction, VT.
Emmert, E.M. 1955. Low-cost plastic greenhouses. Prog. Rpt. Kentucky Agr. Expt. Sta. 28.

Heidenreich, C., M. Pritts, M.J. Kelly, and K. Demchak. 2008. High tunnel raspberries and blackberries. Cornell Univ. Dept. Hort. Publ. No.47. 12 June 2008. <http://www.ces.ncsu.edu/ depts/hort/greenhouse_veg/pdf/high tunnels.brambles.pdf>.

Kansas State University. 2003. High tunnels website. 3 Mar. 2008. <http://www. hightunnels.org $>$.

Kansas State University. 2004. High tunnel discussion listserv archives. 3 Mar. 2008. <http://listserv.ksu.edu/archives/ hightunnels.html>.

Jett, L. 2004. High tunnel tomato production. Univ. Missouri Ext. M170.

Jett, L. 2006. High tunnel melon and watermelon production. Univ. Missouri Ext. M173.

Jimenez, D., R. Walser, and R. Torres. 2005. Hoop house construction for New Mexico: 12 -ft. $\times 40$-ft hoop house. Univ. New Mexico Coop. Ext. Serv. Circ. 606. 27 Jan. 2008. <http://cahe.nmsu.edu/ pubs/_circulars/CR-606.pdf>.

Kadir, S., E.E. Carey, and S. Ennahli. 2006. Growth, yield and fruit quality of two strawberry cultivars (Fragaria ×ananassa Duch.) under high tunnel compared with field conditions. HortScience 41:329-335.

Karlsson, M., H. Rader, and J. Werner. 2007. Seasonal northern snap bean production using high tunnels. HortScience 42:924. (Abstr.).

Knewtson, S. and E. Carey. 2007. Soil quality in high tunnels: Producer perception and reality in the central Great Plains. HortScience 42:899. (Abstr.).

Lamont, W.J. 1996. What are the components of a plasticulture system? HortTechnology 6:150-154.

Lamont, W.J., M.D. Orzolek, E. Jay Holcomb, K. Demchak, E. Burkhart, L. White, and B. Dye. 2003. Production system for horticultural crops grown in Penn State high tunnel. HortTechnology 13:358-362.

Lamont, W.J., M.D. Orzolek, C. Rasmussen, and L. White. 2005. High tunnel production manual. 2nd ed. Pennsylvania State Univ. Dept. of Hort. Ext. Publ. High Tunnel Ser. 1.

Lamont, W.J., M.D. Orzolek, K. Demchak, E. Jay Holcomb, R.M. Crassweller, E. Burkhart, L. White, and B. Dye. 2002. Penn State high tunnel extension program. HortTechnology 12:732-735. 
Lang, G.A. 2009. High tunnel tree fruit production: The final frontier? HortTechnology 19:50-55.

Miles, C. and P. Labine. 1997. Portable field hoophouse. Washington State Univ. Ext. Publ. EB1825, 3 Mar. 2008. <http:// cru.cahe.wsu.edu/CEPublications/ ebl825/ebl825.html>.

Montri, A. and J. Biernbaum. 2009. Management of the soil environment in high tunnels. Hort Technology 19:34-36.

Nennich, T.T., D. Wildung, and P. Johnson. 2004. Minnesota high tunnel production manual for commercial growers. Univ. Minnesota Ext. Serv. M1218. 27 Jan. 2008. <http://www.extension.umn.edu/distribu tion/horticulture/M1218.html>.

Orzolek, M.D., W.J. Lamont, and L. White. 2004. Promising horticultural crops for production in high tunnels in the mid-Atlantic area of the United States. Acta Hort. 633:453-458.
Rader, H.B. and B.G. Karlsson. 2006. Northern field production of leaf and romaine lettuce using a high tunnel. HortTechnology 16:649-654.

Reiss, E., A.J. Both, S. Garrison, W. Kline, and J. Sudal. 2004. Season extension for tomato production using high tunnels. Acta Hort. 659:153-160.

Spaw, M. and K.A. Williams. 2004. Full Moon Farm builds high tunnels: A case study in site planning for crop production structures. HortTechnology 14:449454 .

U.S. Department of Agriculture. 2007. United States 2007 census of agriculture. Natl. Agr. Stat. Serv. form no. 07-A0201. 13 June 2008. <http://www.agcensus.usda. gov/publications/2007/index.asp>.

Wells, O.S. 1996. Rowcovers and high tunnel growing systems in the United States. HortTechnology 6:172-176.

Wells, O.S. and J.B. Loy. 1993. Rowcovers and high tunnels enhance crop production in the northeastern United States. HortTechnology 3:92-95.

Wiediger, P. and A. Wiediger. 2003. Walking to spring. Au Naturel Farm, Smiths Grove, KY.

Wien, H.C. 2009. Floral crop production in high tunnels. HortTechnology 19:5660 .

Wittwer, S.H. 1993. Worldwide use of plastics in horticultural production. HortTechnology 3:6-19.

Wright, B. 2005. The unfrozen tundra: Extending the growing season in Wisconsin. 25 Feb. 2008. <http:// www.co.brown.wi.us/UW_Extension/ CommGardens/High\%20Tunnels.pdf $>$.

Zhao, X., T. Iwamoto, and E. Carey. 2007. Antioxidant capacity of leafy vegetables as affected by high tunnel environment, fertilization, and growth stage. J. Sci. Food Agr. 87:2692-2699. 